\title{
EVALUATION OF SOLVENT EFFECTS ON DRUG RELEASE FROM INJECTABLE PHASE SENSITIVE LIQUID IMPLANT SYSTEMS
}

\author{
ENJEKTE EDİLEBİLEN FAZ DUYARLI SIVI İMPLANT SİSTEMLERDEN ETKİN \\ MADDE SALIMINA ÇÖZÜCÜ ETKİLERINIIN DEĞERLENDİRILMESİ
}

\author{
Evren ALĞIN YAPAR, Tamer BAYKARA*
}

University of Ankara, Faculty of Pharmacy, Department of Pharmaceutical Technology, 06100 Tandoğan-Ankara/TURKEY.

\section{ABSTRACT}

The aim of this study was to investigate effects of solvent type on granisetron hydrochloride release from injectable in situ forming implants. Formulations contained 32\% poly(DL-lactide-co-glycolide) 50:50 (Resomer RG 502), 64\% solvent and 4\% drug by weight. Dimethylsulphoxide (DMSO), N-methyl-2pyrrolidone (NMP), tetraglycol (TG), propylene carbonate $(P C)$, triacetin $(T A)$ and benzyl benzoate $(B B)$ in the rank of decreasing hydrophilicity, were used as solvents. After determination of formulation's injectability through $20 \mathrm{G}$ needles, in vitro dissolution test was carried out in a shaker bath (30 rpm) and samples were analyzed by spectrophotometrically. Drug release profiles showed that initial burst decreased by using hydrophobic solvents in rank of $B B>T A>P C$ and increased by using hydrophilic solvents in rank of $D M S O>N M P>T G$. For following release; DMSO caused a burst (99.1\%) while BB and TA caused very slow release for the first week. BB and TA showed tri-phased profiles for three weeks. NMP and TG gave similar profiles between DMSO and PC. PC gave relatively regular drug release after $25 \%$ in the first day. Dissolution kinetics mostly fitted to Higuchi kinetic model. Results showed that, combination of phase sensitive polymers and moderately hydrophobic solvents can be utilized for modifying release of drug from injectable implant systems for 21 days.

Key words: Granisetron $\mathrm{HCl}$, Poly(DL-lactide-co-glycolide), Phase sensitive, Injectable, In situ implant.

* Corresponding author 


\section{ÖZET}

Bu çalı̧̧manın amacl, in situ oluşan enjektabl implantlardan granisetron hidroklorür salımına çözücü türünün etkilerinin incelenmesidir. Formülasyonlar ă̆ırllkça \%32 poli(DL-laktid-ko-glikolid) 50:50 (Resomer RG 502), \%64 çözücü ve 4\% etkin madde içermektedir. Kullanllan çözücüler, azalan hidrofillik sırasına göre dimetilsülffoksit (DMSO), N-metil-2-pirolidon (NMP), tetraglikol (TG), propilen karbonat (PC), triasetin (TA) ve benzyl benzoat (BB)'ttr. Formülasyonlartn $20 G$ iğnelerden enjekte edilebilirliği saptandlktan sonra, in vitro çözünme hızı testi su banyosunda (30 dev/dak) yürütülmüs ve numuneler spektrofotometrik olarak analiz edilmiştir. Etkin madde salım profilleri, başlangı̧ doz boşalmasının hidrofobik çözücülerin kullanılmasıyla $B B>T A>P C$ sıralamasında azaldığını ve hidrofilik çözücülerin kullanılmaslyla DMSO $>N M P>T G$ sıralamasında arttığın göstermiştir. Takip eden salımda birinci haftada, DMSO doz boşalmasına (99.1\%) neden olurken, BB ve TA çok yavaşs salıma neden olmuştur. BB ve TA ü̧̧ haftada üç-fazl profiller göstermiştir. NMP ve TG, DMSO ve PC arasında yer alan benzer profiller vermiştir. $P C$, birinci günde \%25 ten sonra nispeten düzenli salım vermiştir. Salım kinetikleri çoğunlukla Higuchi kinetik modeline uymuştur. Sonuçlar faz duyarl polimerlerin, orta hidrofobluktaki çözücüler ile kombinasyonlarının enjektabl implant sistemlerden 21 gün boyunca etkin madde salımının düzenlenmesinde yararl olabileceğini göstermiştir.

Anahtar kelimeler: Granisetron HCl, Poli(DL-laktid-ko-glikolid), Faz duyarl, Enjekte edilebilen, In situ implant.

\section{INTRODUCTION}

A major development of the past decade has been the fabrication of implantable delivery systems based on biocompatible or biodegradable polymers. A novel biodegradable injectable polymeric system namely in situ forming implants (ISFIs) has been developed and looks very promising in drug delivery which has disclosed a delivery approach to prolonged zero-order release over 2 weeks to 6 months duration (1-3). The application of in situ forming implants (ISFI) is less invasive and painful compared to pre-shaped implants leading to an improved patient compliance and comfort. The manufacturing conditions are mild and un-complicated, especially for sensitive drug molecules like proteins. After subcutaneous injection ISFI into the body the organic solvent dissipates into the surrounding tissue as water penetrates in. This leads to phase separation and precipitation of the polymer forming a depot at the injection site. The way the implant solutions respond to its physiological surroundings determines their release characteristics and morphology (4). The lag time between injection and formation of the solid implant causes the initial burst release of drug, which may lead to tissue irritation and sometimes systemic toxicity (5). To control the initial burst effect four factors which influence the dynamic polymer precipitation, such as 
concentration of the polymer in polymeric solution (6), molecular weight of the polymer (6-8) the organic solvent used (8-10) and the addition of an additive $(5,11)$ have been investigated and still under investigation.

Drug therapy in a patient with cancer often requires co-administration of several medications. Severe nausea and vomiting are frequently associated with many cytotoxic chemotherapeutic agents and are a major cause of distress to the patient. Granisetron $\mathrm{HCl}$ (GRN $\mathrm{HCl}$ ) is a serotonine type potent and high selective $5-\mathrm{HT}_{3}$ receptor antagonist which is effective in preventing chemotherapy-induced emesis following intravenous or oral administration (12).

The objective of this study is to evaluate the effects of solvent type on GRN HCl release from injectable polymeric implant system formed in situ by polymer precipitation mechanism for 21 days.

\section{MATERIALS AND METHODS}

\section{Materials}

The following chemicals were obtained from commercial suppliers: Granisetron hydrochloride (Cipla Limited, India), poly(d,1-lactide-co-glycolide) (PLGA 50:50, Resomer RG $502 \mathrm{M}_{\mathrm{w}} 18 \mathrm{kDa}$ ) (Boehringer Ingelheim $\mathrm{GmbH}$, Ingelheim, Germany), Dimethylsulphoxide (Merck), N-methyl-2- pyrrolidone (Merck), Tetraglycol (Sigma), Propylene carbonate (SigmaAldrich), Triacetin (Sigma), Benzyl benzoate (Sigma), Disodium hydrogen phosphate (Merck), Potassium dihydrogen phosphate (Merck), Sodium chloride (Merk).

\section{Preparation of the in situ forming drug delivery systems}

In situ implants (polymer solutions) were prepared by mixing PLGA with the solvents (DMSO, NMP, TG, PC, TA or BB) in glass vials until the formation of a clear solution and then GRN HCl was dissolved/suspended (Bandelin Sanoplus HD 2070, Germany) in polymer solution. Air bubbles in implant formulations were removed by heating $65^{\circ} \mathrm{C}$ of sealed containers. The polymer, solvent and drug concentration was kept constant at 32\%, 64\% and 4\% (w/w) respectively. The code and content of formulations is given in Table 1. 
Table 1. The code, content (given in $\mathrm{mg}$ ) and injectability of in situ implant formulations.

\begin{tabular}{|c|c|c|c|c|c|c|}
\hline Content/Code & F1 & F2 & F3 & F4 & F5 & F6 \\
\hline DMSO & - & - & - & - & - & 300 \\
NMP & - & - & - & - & 300 & - \\
TG & - & - & - & 300 & - & - \\
PC & - & - & 300 & - & - & - \\
TA & - & 300 & - & - & - & - \\
BB & 300 & - & - & - & - & - \\
Resomer RG 502 & 150 & 150 & 150 & 150 & 150 & 150 \\
GRN HCl & 20 & 20 & 20 & 20 & 20 & 20 \\
\hline $\begin{array}{l}\text { Injectability } \\
\text { (20G needle) }\end{array}$ & Yes & Yes & Yes & Yes & Yes & Yes \\
\hline
\end{tabular}

\section{Drug release studies}

After injectabilities of all formulations from $20 \mathrm{G}$ needle were determined (Table 1), formulations were injected in $10 \mathrm{ml}$ phosphate buffer saline $\mathrm{pH} 7.4$ containing vials and in vitro dissolution test were carried out in a shaker bath (GFL 1086, Germany) at $30 \mathrm{rpm}$ and $37^{\circ} \mathrm{C}(\mathrm{n}=3)$. Replenished, collected and filtered dissolution media at predetermined time points (1h, 4h, 24h, once a day through 2-21 days) were analyzed by UV spectrophotometer (Shimadzu 1240, Japan) at $301 \mathrm{~nm}$ (after accomplished calibration and method validation stages) and drug release profiles were obtained. Drug release kinetics was evaluated by Zero order, First order, Higuchi and Korsmeyer-Peppas kinetic models which were calculated by GraphPad Instat 3.0.

\section{RESULTS AND DISCUSSION}

In this study the effects of solvents on drug release were compared and evaluated by means of their solubility parameter $\log \mathrm{P}$ (1-oktanol/water partition coefficient) which were calculated by ALOGPS 2.1 on-line software program (13). Important properties of solvents were given in Table 2 (14). As seen in Table 2, all of the solvents were liquid at temperatures of injection $\left(24^{\circ} \mathrm{C}\right)$ and dissolution $\left(37^{\circ} \mathrm{C}\right)$. Their amounts in formulations were under the toxicity limits for human that was predicted from $\mathrm{LD}_{50}$ values as seen in Table 2 and their water solubility's decreased in the rank of DMSO, NMP, TG, PC, TA, BB according to their values of LogP. Since injectability is an important consideration for polymer solutions, formulations prepared with different solvents were 
tested to see if they were injectable through a $20 \mathrm{G}$ needle. As seen in Table 1, all formulations containing solvents having different solubility were injectable through a $20 \mathrm{G}$ needle. However injection of formulations became a bit difficult due to increasing hydrophobic character of solvent present in the formulation.

Table 2. Properties of solvents used in in situ forming injectable implant systems (14).

\begin{tabular}{|c|c|c|c|c|}
\hline Solvent & $\log P$ & Melting point $\left({ }^{\circ} \mathrm{C}\right)$ & Boiling point $\left({ }^{\circ} \mathrm{C}\right)$ & $\mathrm{LD}_{50}(\mathrm{mg} / \mathrm{kg})$ \\
\hline DMSO & -1.09 & +18.5 & +189 & $\begin{array}{c}\text { IV, rat: } 5360 \\
\text { IP, rat: } 8200 \\
\text { SCU, rat: } 12000 \\
\text { Oral, rat: } 14500 \\
\text { Dermal, rat: } 40000\end{array}$ \\
\hline NMP & -0.71 & -24 & +202 & $\begin{array}{c}\text { IV, mice: } 155 \\
\text { IP, mice: } 3050 \\
\text { Oral, rat: } 3914 \\
\text { Dermal, rabbit: } 8000\end{array}$ \\
\hline TG & -0.07 & +6 & $\begin{array}{r}+145 \\
\end{array}$ & $\begin{array}{c}\text { IV, mice: } 57 \\
\text { Dermal, rabbit: } 20000 \\
\end{array}$ \\
\hline $\mathrm{PC}$ & 0.14 & -50 & +243 & $\begin{array}{c}\text { Oral, rat: } 29100 \\
\text { Dermal, rabbit:20001 }\end{array}$ \\
\hline TA & 0.40 & +3 & +260 & Oral, rat: 3000 \\
\hline BB & 3.43 & +18 & +323 & $\begin{array}{c}\text { Oral, rabbit: } 1680 \\
\text { Dermal, rabbit: } 4000\end{array}$ \\
\hline
\end{tabular}

IP: Intra peritoneal, SCU: Subcutaneous, IV: Intravenous

Drug release profiles of investigated in situ implant formulations were given in Fig. 1. After injection, solidification duration of formulations was affected by water affinities of solvents and polymer holding in formulations. Resomer RG 502 which was used in all formulations has esterified $-\mathrm{COOH}$ groups hence water would not be attract to the polymer initially at solidification duration and this amorphous polymer would lead to denser depot formation dependent by using solvent. So the main parameter would be the water affinities of solvents on solidification and drug release process.

As seen in Fig. 1, F6 formulation containing DMSO showed the fastest-burst like release of drug with approximately $80 \%$ initial release in the first day (24 h). F5 and F4 containing NMP and TG respectively showed very similar and slower release of drug than F6 formulation. The advantage of hydrophilic solvents in this system is getting fast formation but sponge like depots which can be useful to control the release of active agent (15). Although drug amount is only $4 \%$ in formulations, probably due to low $\mathrm{M}_{\mathrm{w}}$ and high water solubility of GRN $\mathrm{HCl}$, drug release 
occurred as burst release from F6, F5 and F4. While DMSO which has highest water solubility (water soluble) showed the highest initial and fastest release of drug from F6, NMP (water miscible) and TG (30\% water miscible) which was different in their water solubility's gave very similar drug release profiles. However, drug release was more uniform from F4 containing TG, probably due to TG's relatively lower hydrophilicity.

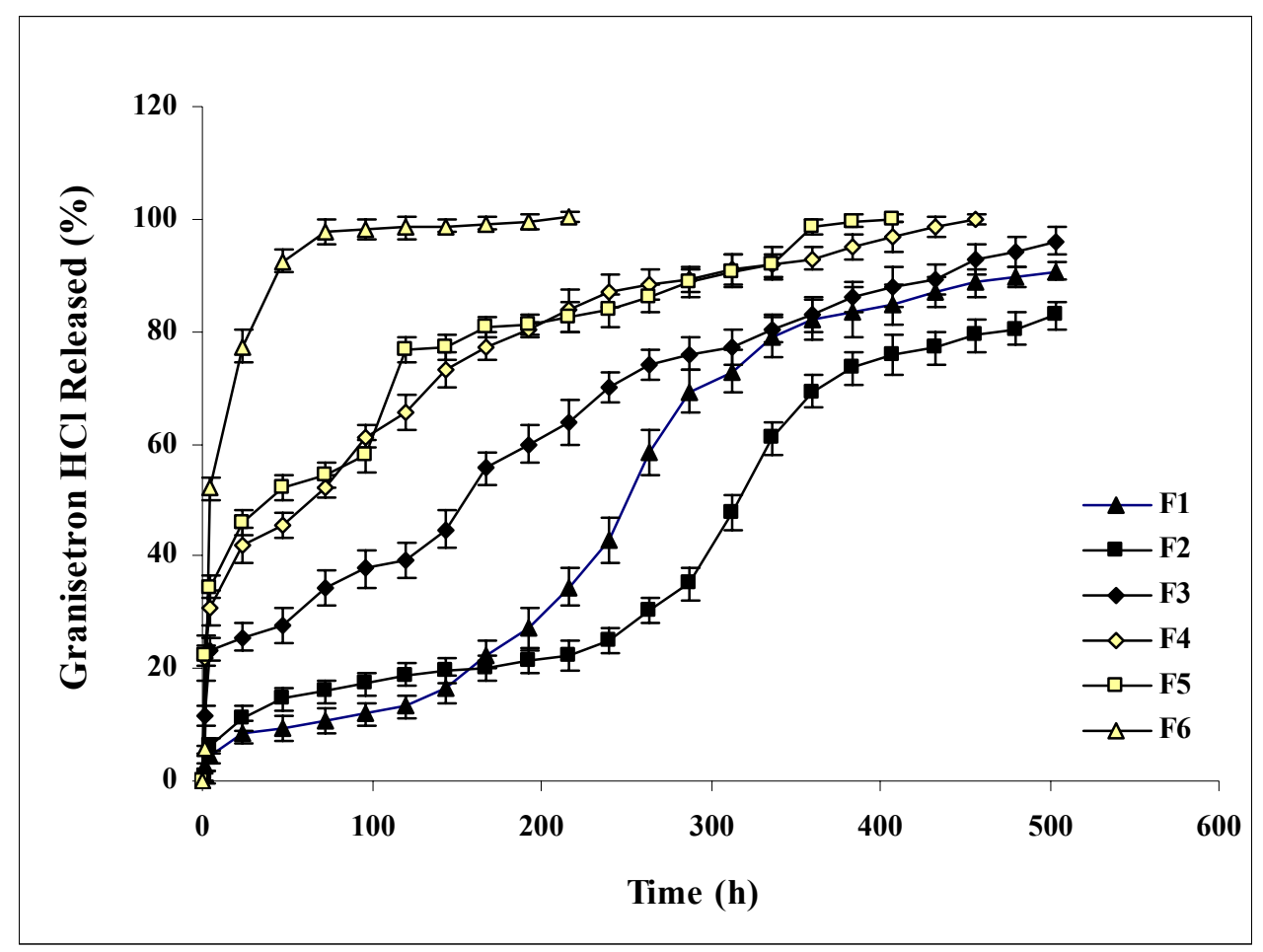

Figure 1. Drug release profiles of investigated in situ implant formulations.

The initial burst of drug in the first day decreased to approximately $25 \%$ by using PC in F3 formulation (Fig. 1). Moderately hydrophobic PC (17.5\% water soluble) decreased the initial burst as well as release rate of drug which resulted as a more uniform drug release profile compared with F4. This could be attributed the moderate phase inversion rate of formulation that reduced pore formation due to PC's lower water solubility's. Increasing hydrophobic properties of solvents resulted as an inhibition in initial burst and decrease in drug release especially in the first week (168 h) from F1 and F2 formulations containing BB and TA respectively due to slow phase separation and formation of dense depots as a result of reduced pores. These results are in accordance with the study of McHugh which reported the relation between solvent properties and phase separation rate (16). Unexpectedly drug release more increased from F1 than F2 after the 
first week. This result could be attributed to the duration of depot formation. From this point of view while depot formation took long time with non-water soluble $\mathrm{BB}$, it would be relatively fast with TA which has a water solubility of $1-10 \%$ (16). Water soluble and low $\mathrm{M}_{\mathrm{w}}$ drug would relatively easily release from low viscosity depot containing $\mathrm{BB}$ than more viscous depot containing TA. However drug release profiles of F1 and F2 were in same manner over 21 days and these results are supported by the data of Brodbeck et al. (17).

Kinetic evaluation of investigated in situ implant formulations which were given in Table 3 showed that highest determination coefficient $\left(\mathrm{r}^{2}\right)$ and lower residual mean square (RMS) values (18) were obtained for Higuchi kinetic model from F6, F5, F4 and F3 containing solvents which are water soluble or can be accepted as moderately water soluble. Although highest $\mathrm{r}^{2}$ and lowest RMS values were obtained for Zero order kinetic model from F1 and F2 containing hydrophobic solvents, the release profiles of these formulations were not support this result as seen in Fig 1. Comparison of all formulations showed that better release profile was obtained with F3 containing moderately water soluble PC and an absolute kinetic evaluation was hard for those formulations.

Table 3. Kinetic evaluation of investigated in situ implant formulations.

\begin{tabular}{|c|l|cccccc|}
\hline Model & Parameter & F1 & F2 & F3 & F4 & F5 & F6 \\
\hline \multirow{3}{*}{ Zero } & $\mathrm{k}_{\mathrm{o}}$ & 0.0416 & 0.0338 & 0.0322 & 0.0300 & 0.0321 & 0.0463 \\
Order & $\mathrm{S} E$ & 0.0412 & 0.0332 & 0.0292 & 0.0854 & 0.0497 & 0.0585 \\
& $\mathrm{r}^{2}$ & $\mathbf{0 . 9 4 5 8}$ & $\mathbf{0 . 9 1 9 5}$ & 0.9607 & 0.8732 & 0.8729 & 0.7709 \\
& $\mathrm{R} M S$ & $\mathbf{7 4 . 7 6}$ & $\mathbf{6 9 . 8 3}$ & 526.7 & 2017 & 2128 & 2479 \\
\hline & $\mathrm{k}_{1}$ & 0.0005 & 0.0004 & 0.0004 & 0.0003 & 0.0004 & 0.0005 \\
First & $\mathrm{SE}$ & 0.0020 & 0.0020 & 0.0030 & 0.0070 & 0.0030 & 0.0040 \\
Order & $\mathrm{r}^{2}$ & 0.9334 & 0.8677 & 0.9679 & 0.8018 & 0.6957 & 0.8873 \\
& $\mathrm{RMS}$ & 310.9 & 222.6 & 19.04 & 116.6 & 475.5 & 313.5 \\
\hline & $\mathrm{k}$ & 1.010 & 0.8000 & 0.8204 & 0.7625 & 0.7643 & 0.9906 \\
Higuchi & $\mathrm{SE}$ & 0.3130 & 0.1750 & 0.2550 & 0.7180 & 0.2780 & 0.2770 \\
& $\mathrm{r}^{2}$ & 0.8665 & 0.8030 & $\mathbf{0 . 9 7 2 5}$ & $\mathbf{0 . 9 7 8 7}$ & $\mathbf{0 . 9 6 9 3}$ & $\mathbf{0 . 9 2 0 7}$ \\
& $\mathrm{RMS}$ & 165.6 & 165.3 & $\mathbf{1 6 . 8 5}$ & $\mathbf{1 2 . 4 0}$ & $\mathbf{1 6 . 8 1}$ & $\mathbf{6 4 . 5 0}$ \\
\hline & $\mathrm{n}$ & 0.5126 & 0.5936 & 0.1128 & 0.2136 & 0.2167 & 0.2966 \\
& SE & 0.0690 & 0.1579 & 0.0238 & 0.0287 & 0.0101 & 0.0848 \\
Korsmeyer & $\mathrm{r}^{2}$ & 0.8214 & 0.8839 & 0.9031 & 0.9661 & 0.9509 & 0.9090 \\
-Peppas & RMS & 0.0330 & 0.0249 & 0.0032 & 0.0008 & 0.0018 & 0.0072 \\
\hline
\end{tabular}




\section{CONLUSION}

As a conclusion moderately water soluble solvents can be useful to develop a modified release of low $\mathrm{M}_{\mathrm{w}}$ water soluble active agent from an injectable biodegradable PLGA implant system over 21 days.

\section{REFERENCES}

1- Dunn, R.L., English, J.P., Cowsar, D.R., Vanderbilt, D.P. "Biodegradable in-situ forming implants and methods of producing" US Patent, 5990194, (1999).

2- Hatefi A., Amsden B. "Biodegradable injectable in-situ forming drug delivery systems" $J$. Control Release, 80, 9-28, (2002).

3- Packhaueser, C.B., Schneiders, J., Oster, C.G., Kissel, T. "In situ forming parenteral drug delivery systems" Eur. J. Pharm Biopharm., 58, 445-455, (2004).

4- Kempe, S., Metz, H., Mäder, K. "Do in situ forming PLG/NMP implants behave similar in vitro and in vivo? A non-invasive and quantitative EPR investigation on the mechanisms of the implant formation process" J. Control. Release, 130(3), 220-225, (2008).

5- Bakhshi, R., Vasheghani-Farahani, E., Mobedi, H., Jamshidi, A., Khakpour, M. "The effect of additives on naltrexone hydrochloride release and solvent removal rate from an injectable in situ forming PLGA implant." Polym. Adv. Technol., 17, 354-359, (2006).

6- Eliaz, R.E., Kost, J. "Characterization of a polymeric PLGA-injectable implant delivery system for controlled release of proteins" J. Biomed. Mater. Res., 50, 388-396, (2000).

7- Astaneh, R., Erfan, M., Moghimi, H.R., Mobedi, H. "Changes in morphology of in situ forming plga implant prepared by different polymer molecular weight and its effect on release behavior" J. of Pharm. Sci., DOI 10.1002/jps.21415, (2008).

8- Lambert, W.J., Peck, K.D. "Development of an in situ forming biodegradable poly-lactide-coglycolide system for the controlled release proteins. J. Control. Release, 33, 189-195, (1995).

9- Ravivarapu, H.B., Moyer, K.L., Dunn, R.L. "Parameters affecting the efficacy of a sustained release polymeric implant of leuprolide. Int. J. Pharm., 194(2), 181-191, (2000).

10- Algın Yapar, E., Baykara, T. "Effects of solvent combinations on drug release from injectable phase sensitive liquid implants" Turkish J. Pharmaceutical Sciences, 7(1), xx, (2010), (in press). 
11- Chandrashekar, B.L., Zhou, M., Jarr, E.M., Dunn, R.L. "Controlled release liquid delivery compositions with low initial drug burst" US Patent 6143314, (2000).

12- Matti, S.A. "5-HT $\mathrm{HT}_{3}$ receptor antagonists: an overview of their present status and future potential in cancer therapy-induced emesis" Drugs, 42, 551-568, (1991).

13- ALOGPS 2.1 Virtual Computational Chemistry Laboratory, (2001). http://www.vcclab.org/lab/alogps/

14- Alğın Yapar, E. "Development of Sustained Drug Delivery Systems as In situ Forming Injectable Implants" PhD Thesis, (2009).

15- Mchugh, A.J. "The role of polymer membrane formation in sustained release drug delivery systems" J. Control. Release, 109, 211-221, (2005).

16- J.T. BAKER INC. (2006). http://www.jtbaker.com/msds/englishhtml/t4569.htm

17- Brodbeck, K.J., Desnoyer, J.R., Mchugh, A.J. "Phase inversion dynamics of PLGA solutions related to drug delivery. Part II. The role of solution thermodynamics and bath-side mass transfer" J. Control. Release, 62(3), 333-344, (1999).

18- Alpar, R., Öner, L. “Regresyon çözümlemesi” Fabad J. Pharm. Sci., 13, 556-565, (1988). 